\title{
Developing Illustrated Story Books to Improve Beginning Reading Skills and Learning Motivation
}

\author{
Felix Baskara Bhakti Utomo \\ Universitas Sarjanawiyata Tamansiswa. Jalan Batikan UH-III/1043 Yogyakarta, 55167, Indonesia \\ *Corresponding Author. Email: agatha.devi99@gmail.com \\ Received: 20 October 2017; Revised: 25 September 2018; Accepted: 10 October 2018
}

\begin{abstract}
This research aimed (1) to produce a suitable illustrated story book in improving the students' reading skill and learning motivation, and (2) to know the effectiveness of the illustrated story book media for the beginning reading skills and learning motivation of the first grade students of SD Negeri Timbulharjo Sewon Bantul. The research method used was research and development (R\&D) which referred to the 10 steps developed by Borg and Gall (1983) and the determination of the number of subjects refers to the opinion of Dick and Carey (2005). The subjects of the try out were the first grade students of SD Negeri Timbulharjo 1 Sewon Bantul. The data were collected by using interview, observation, scale, performance test and worksheet. The techniques of analyzing data employed on this research were need analysis, the feasibility study media, and analysis of effectiveness of media. Normality test used using Shapiro-Wilk because data less than 50. The result of the research was (1) a set of illustrated story book media that fulfilled the feasibility based on validation by a material expert and a media expert, and teachers' and students' response which was in very good category; (2) the developed illustrated books media were effective to improve the beginning reading skills and students' learning motivation. Beginning reading skills and students' learning motivation increased significantly based on paired t-test with probability score $(\mathrm{p})<0.05$.
\end{abstract}

Keywords: illustrated story book, beginning reading skills, learning motivation

How to Cite: Utomo, F. (2018). Developing illustrated story books to improve beginning reading skills and learning motivation. Jurnal Prima Edukasia, 6(2), 118-128. doi:http://dx.doi.org/10.21831/jpe.v6i2.16456

Permalink/DOI: http://dx.doi.org/10.21831/jpe.v6i2.16456

\section{Introduction}

Education is an important part to improve the quality of human resources, so the humans are able to solve life problems, become mature and have character. According to Law Number 20 Year 2003 article 3 on National Education System, it is stated that the National Education functions are to develop ability, to form character and dignified nation civilization, to educate the life of the nation, and to develop students' potential to become humans who believe and fear the Almighty God, noble, healthy, knowledgeable, capable, creative, independent, and become democrats and responsible citizens. To create the knowledgeable generation, there are many influential factors and one of them is the student learning motivation.

Related to students' learning motivation, Hamdu \& Agustina (2011, pp 90-96) state that students' learning achievement are influenced by many factors and one of them is by learning motivation. Students who have learning motivation means they have the encouragement or desire to learn and finish the task given by the teachers. To improve students' learning motivation, it is important for teachers to create interesting material which attracts students to learn. Students who do not have the learning motivation tend to be lazy and slow in understanding materials. The low learning motivation also influences students in reading.

For elementary school students, reading is the basis to learn various subjects. If students do not have the ability to read, they will face difficulties to learn various subjects in higher level/grade. The average reading level index in the developed countries is $0,45-0,62$. According to the survey of United Nations Educational, Scientific and Cultural Organization (UNESCO) in 2011 (in Koran Sindo Daerah, 2016), reading level index of Indonesian society is only $0,001 \%$. This means that there is only 1 among 1000 people who still wants to read book seriously. 
Jurnal Prima Edukasia, 6 (2), July 2018 -119

Felix Baskara Bhakti Utomo

This condition places Indonesia in the position of 124 among 187 countries in the assessment of human development index.

Due to that condition, the beginning research was conducted on August $4^{\text {th }}-6^{\text {th }}, 2016$ in the learning process of the first grade of State Elementary School in Timbulharjo, Sewon. Interview and observation were conducted during the learning process in the class. Based on the results of interview and observation, almost $20 \%$ of the total 66 students have low learning motivation. This is the cause why the students cannot read fluently in the beginning. Besides that, the students lack of enthusiasm to join the class. There are many students who play around, ask permission to go to the restroom, and do not pay attention to the teachers' explanation. Furthermore, the teaching and learning process is only based on the textbook of Education Unit Level Curriculum (KTSP) since the thematic books of curriculum 2013 are not available at school. Due to this case, teachers' should improve their creativity in teaching by the use of the media and new method. In today's education, the learning media is extremely important to run the learning process effectively.

Based on the problem emerged in the field, it is necessary for teachers to conduct the fun learning process. To solve the problem, the illustrated story books are developed to help teachers to create the fun learning process which can improve students' learning motivation and beginning reading skill.

Almost all the learning media provided in State Elementary School of Timbulharjo are for the $4^{\text {th }}, 5^{\text {th }}$, or $6^{\text {th }}$ grade. This means that the learning media for the $1^{\text {st }}, 2^{\text {nd }}$, and $3^{\text {rd }}$ grade are limited and not various. Teachers thought that the learning media for the higher grade are more prioritized than the lower grade since the materials for the higher grade are many.

Since illustrated story books are not available at this school, then this research is developed. The books are only for the first grade in order to develop their learning motivation and beginning reading skill.

The research conducted by Suwandi dan Masruri (2016) shows that picture books using the development model of Dick, Caray, \& Carey (2005) can improve the learning motivation and learning comprehension of the $5^{\text {th }}$ grade students. The learning process using the innovative media is more interesting to students since most teachers only deliver the materials by lecturing. Lecturing is only centered to the teacher and relies on the teachers' speaking skill in delivering the material. This makes the students feel bored to join the learning process in the class. Therefore, the learning media can improve students' learning motivation since it is more interesting than the learning without media.

The use of illustrated books is an effective way to give children experience of reading. The illustrated books have less vocabularies which stimulate the children to love reading. The striking color of the books can improve children's beginning reading skill, motivate them to read, and arouse their curiosity. The other benefit of using illustrated books is gaining the students' attention to keep focus reading the story. Besides, in education, generally the illustrated books are applied to students of kindergarten and first grade to improve their beginning reading skill. Students who read illustrated books will feel easy to understand the meaning of the words.

Illustrated story books are the result of printing technology which contains the message of written text and illustration. These are the important elements of the story. Levey \& Polirstok (2011, p.130) states that illustrated story books give information by using the verbal language (symbol) and picture (icon). The delivered information are different according to the intended age level.

Illustration and text are the important elements of the illustrated story books and they become the source of information which conveys message to readers through stories and pictures. Therefore, the illustrated story books can stimulate children to have strong desire to read.

Illustrated story books have some advantages as stated by Mitchell, Waterbury, \& Casement (2002, pp. 87-91): (1) illustrated story books can help children's cognitive and emotional development. Children feel facilitated and helped to understand themselves and other and they can express their various emotions, (2) illustrated story books help children to learn about the world. Through illustrated story books, children can learn about the life of society in the past and present, the geographical condition, the nature, the plants and animals. The books will help children to add their life experience during their growth, (3) illustrated story books facilitate children to get fun. Children feel fun and happy by seeing the good, interesting, and funny pictures which can make them laugh, (4) illustrated story books help children to appreciate the beauty. The beauty can be seen both in the verbal and illustration. The verbal beauty are from the 
Jurnal Prima Edukasia, 6 (2), July 2018 -120

Felix Baskara Bhakti Utomo

interesting plot and character while the beauty of the illustration can be seen in the accuracy of the object depiction, color composition, and various interesting action, (5) illustrated story books can stimulate children's imagination. Through stories, their imagination have developed and the illustration complete the concrete and strong stories. Therefore, the illustrated story books can improve children's understanding of stories and stimulate their imagination.

The illustrated story books can also improve other language skills (reading and listening). Faizah (2009, p.19) states that by using illustrated story books, it will be easier for students to understand the content of the books since the books contain interesting pictures.

In spite of having the advantages, the illustrated story books also have some disadvantages. Sudjana \& Rifai (2010, p.72) mention the disadvantages of the illustrated story books as the following: (1) the pictures are not big enough to teach in the big class, (2) the books are only in two dimensions, not three dimensions as needed, (3) the books cannot show the movement like live pictures.

The steps of creating illustrated books can be adjusted to the need of the writer and the developed materials. Susiani (2006, pp.6-7) explains the steps of creating illustrated story books as the following: (1) formulation of stories ideas and characters. This is the most important steps to make the series of the stories becomes stronger. Formulation of the stories ideas is started by creating the summary of the stories. The summary is the same as the outline of the story. (2) Sketch making. After creating the formulation of the stories ideas and characters, the next step is the sketch making. It is conducted by using tools like papers, pencils, erasers, and rulers. (3) Sketch inking. After the process of sketch making, then the sketch inking process is conducted. The process of inking is conducted by using ink, pen, or marker on the sketch. (4) Coloring. The next process is coloring. It can be done manually by using the paints or poster paints or by the software of a computer. The digital method of coloring the illustrated story books usually uses the Corel Draw software. (5) Lettering. The process of lettering can be done manually or digitally. The lettering of the illustrated story books should concern the pictures position and not covering them.

Beginning reading at elementary school especially to the first and second grade should be stressed on understanding and pronouncing the words correctly. Beginning reading skill becomes the basis for the further reading at the higher level. If students' beginning reading skill is already good, they will not experience any significant difficulties in the future.

Beginning reading at elementary schools aimed at mastering the basic reading skill to make the further reading becomes easier. The purpose of beginning reading are to know each element of the writing and speak the word clearly with the right intonation and pronunciation.

Beginning reading is an ability that must be possessed by the first and second grade students to know various symbol of language. Students should be able to read with the right pronunciation and intonation as the basis to continue to the further reading.

To achieve the good reading skill, parents and teachers at school should guide the children seriously. Akhadiah (1992, p.32) state that some beginning reading methods are alphabets sound, peel syllables, word institution, global, and SAS. In practicing beginning reading, it should be adjusted to the students' situation and characteristics. The methods mentioned pre-viously are all good and each has its own advantages and disadvantages.

The preparation of beginning reading should be adjusted to the development of children reading skill. Supartini (2001, p.79) states that the two steps of beginning reading preparation are visual ability and auditory ability. Training the visual ability can be practiced through: (1) matching pictures, it is the process of matching the word with the picture. It becomes the initial step to grow the children awareness of the words. (2) Matching the shape, if children are able to select the picture with the same shapes, then they can be trained to match the shape of the words. It can be practiced if the children language skill is already good. (3) Matching the writing/words with the pronunciation, teachers can show the words and read them aloud at the same time. The previous activity is also called as reading.

One thing to consider before preparing beginning reading is doing assessment to decide the right method used. The assessment is needed to know the level of children ability. For children who have difficulties in learning, the assessment can help finding the kind of difficulties and the appropriate teaching strategies. The appropriate teaching method is needed since the ability of the children are various.

Beginning reading skill is a complex matter. The more complex the skills, the more 
Jurnal Prima Edukasia, 6 (2), July 2018 -121

Felix Baskara Bhakti Utomo

factors influence them. Lamb and Arnold (Rahim, 2008, p.16) state that reading ability is influenced by four factors: physiology (physiological condition, neurological consideration, and fatigue), intelligence, environment (students' background, family, and social economy), psychology (motivation, interest, social maturity, emotions, and self-adjustment). The previous factors mentioned can be the inhibitors for students to improve their reading skill, however, the problem can be solved by improving their motivation. Motivation is really influential for students' beginning reading skill.

Motivation is one of the factors that influences the students to gain the learning achievement optimally. Among many factors that influence the learning outcomes, motivation is the most dominant. Teachers should motivate the students to achieve the goal they dream. Elliot, Kratochwill, Cook \& Traves. (2000, p.332) state that motivation can be defined as a state of inside which moves someone to act, supports from a certain direction, and keeps in the certain activities.

The word motive is the base form of the word motivation. It is important for teachers to motivate their students to do the tasks at schools and at home. Motivation is one of the most important element in self-regulation of each individual (Moldovan, 2014, p. 203).

Furthermore, Byrnes (2008, p.100) states that motivation is the basis used to explain the beginning, direction, intensity, perseverance of someone's behaviour in a certain time. If students feel motivated, their behaviour and intensity of learning will improve. As a result, their learning achievement will be better. Other opinion as stated by Schunk (2012, p.346) that motivation is a concept of explanation which helps us to understand why people do certain behaviour. Motivation cannot be observed directly but through the concluded activities directed at a certain goal.

Motivation of each student is different. Brophy (2013, p.3) states that motivation is a construct of hypothesis which explains why people do what they want to do. In this case, motivation is described as direction of appropriateness of students' behaviour about what the students should do related to their position as a learner. Students who have motivation can give the explanation why they study harder.

Learning motivation is a factor that influence someone's desire to do the learning activity. Due to the desire, independence, interest, and awareness to achieve the goal and the encouragement from the outside, the students will improve their learning. Elementary school students who have the motivation can have the desire to be successful and encourage themselves to learn and to grow their own enthusiasm.

The learning motivation of the students do not suddenly appear, it appears as the result of doing activities related to encouragement, desire, and purpose. Therefore, Santrock (2011, p.441) mentions that motivation can be divided into two: (1) extrinsic motivation, is the motivation influenced from the outside of the students, for example the students study hard in order to get the better mark. The extrinsic motivation is needed by the students especially for those who are not interested in certain subject. The encouragement from the outside like giving reward or punishment will give positive impact for the students, (2) intrinsic motivation, is the internal motivation to do something for its own purpose. It means that the motivation appears from the inside of the students themselves. For example, a student read a book for his own need and not for the reward. Besides, most of students who are interested in certain materials have their own purpose to add the knowledge, to improve certain skill, and to achieve the dreams.

Motivation from the inside of the students will be more permanent since it appears without the encouragement from other people. Otherwise, the extrinsic motivation is needed for someone who wants to achieve his goal. Both extrinsic and intrinsic motivation can be used as the encouragement for students to gain the better learning achievement. Motivation from the teachers is also needed to improve the students' learning motivation. The teachers can use illustrated story books to motivate the students to learn.

Motivation is a power from inside or outside of someone to do something. Related to the learning process and achievement of students at elementary schools, motivation has some functions. The functions of motivation according to Hamalik (2004, p.175), are to: (1) encourage behavior or action, in this case is to learn, (2) direct the action to the achievement, (3) drive the action or behavior, like a car machine. The size of the motivation determines the speed of a work. Those three functions become the keywords of the word motivation itself. Students who have high learning motivation will have more chances to succeed than those who have low learning motivation. Hidayat \& Dwiningrum (2016, p. 43) state that the motivation given by the teachers 
Jurnal Prima Edukasia, 6 (2), July 2018 -122

Felix Baskara Bhakti Utomo

must be adjusted to the age and the development of the students. The aim is that the students can accept with pleasure the motivation given by the teachers. The extrinsic motivation given by the teachers is expected to encourage the intrinsic motivation from the inside of the students.

Basically, motivation can help to understand and explain the students' behavior in the learning process. There are some important points of motivation of students at elementary school during the learning process. Uno (2008, p.27) states that there are four points that determine the role of learning motivation of elementary school students: (1) to strengthen the learning, motivation has the role to strengthen the learning of the students. If the students have problems in learning, for example in science class, they can ask for a help to the teachers. The effort to ask for a help to the teachers is the role of motivation to strengthen the learning, (2) to clarify the objectives to be achieved, in this case the role of motivation is related to the significance of learning. The students will be interested to learn something, if they have understood the benefit of it. For example, the students will have high learning motivation, if they have known the benefit of learning computer science which is to improve their technological skill, (3) to determine the various control to the learning stimulus, learning is an activity which involves both physical and psychological condition. Students will not study harder without the strong encouragement from the inside and outside factors. They do the learning activity since there is an encouragement that drive them. Motivation is the stimulus or the drive to learn, (4) to determine the learning perseverance, students who are motivated to learn something will learn seriously and diligently and expect the better learning outcome. In shorts, the motivation to learn something stimulates the students to learn more seriously.

To improve students' learning motivation, there are many strategies that should be conducted by teachers. According to Fathurrohman \& Sutikno (2014, pp. 20-21), the strategies are: (1) explaining the purpose of learning to students, teachers should give explanation about the objectives achieved of the learning process before starting the class, (2) giving reward, this would be interesting for students. The motivation can be in a form of giving reward or doing fun activities, though this isn't effective, (3) creating competition, teachers may create the positive competition among the students in order to improve their learning motivation, (4) Giving praise, teachers can give praise to students and it will increase their enthusiasm, (5) giving punishment, it will be effective to give the deterrent effect to students, (6) Encouraging the students, teachers should give more attention to students and encourage them to get used to learn, (7) Forming the good learning habit, by giving homework and assignment, it would help the students to get used to learn at home, (8) helping students' learning difficulties, teachers can help the students to solve the difficulties individually or in a group, (9) using various teaching method, teachers should apply various teaching method so the students won't feel bored, (10) using good and appropriate media, the media choosing should be correct in order to make the students easy to understand the material.

\section{Method}

The type of the research is Research and Development (R \& D) aimed at creating product of a learning media. The product is illustrated story books which are appropriate and effective to improve students' beginning reading and learning motivation. The product development used Borg \& Gall (1983) development model.

The research development was conducted at State Elementary School of Timbulharjo, Sewon, Bantul at May $8^{\text {th }}$ to June $16^{\text {th }} 2017$. The subjects of this research were the first grade students of State Elementary School of Timbulharjo, Sewon, Bantul which consists of three classes. Each class has 22 students. In the initial field test, the numbers of tryout subjects were 3 students who has the criteria of high, medium, and low academic intelligence. In the field test, the tryout subjects were increased to 12 students. In the operational field test, the tryout subjects were 44 students.

The development procedure was using the steps of Borg \& Gall (1983) model which consists of ten steps as the following: (1) Research plan, (2) Research and data collection, (3) Initial product development, (4) Initial field tryout, (5) Revision of initial field tryout results, (6) Field tryout, (7) Revision of field tryout results, (8) Field implementation test, (9) Revision of final product, (10) Mass production and product dissemination

To create the development product of illustrated story books which are appropriate and effective, the instruments which can dig the data were needed to develop the learning media. The instruments used in this research were interview 
guidelines, expert judgment from the material expert and media expert, response questionnaire scale of students and teachers, observation sheet of students' learning motivation, and beginning reading skill test.

The data analysis techniques used in this research were qualitative and quantitative. The analysis of each data was described as the following: (1) need analysis, it was the data taken from the initial observation and interview, (2) media feasibility test data, the analysis of illustrated story books feasibility were taken from all calculation of the responses from students and teachers, and the assessment from the media expert and material expert. The quality of developed illustrated story books were in a form of scores and then the scores were changed into qualitative data with the five scale reference. The reference of changing scores into five scale according to Widoyoko \& Qudsy (2009, p.238) can be seen in Table 1 .

Table 1 Score Conversion Reference to Scale 5

\begin{tabular}{ccc}
\hline Value & Score & Category \\
\hline A & $\mathrm{X}>\bar{X} \mathrm{i}+1,8 \times \mathrm{Sbi}$ & very good \\
B & $\bar{X}+0,6 \times \mathrm{SBi}<\mathrm{X} \leq \bar{X} \mathrm{i}+1,8 \times \mathrm{SBi}$ & good \\
C & $\bar{X}+0,6 \times \mathrm{SBi}<\mathrm{X} \leq \bar{X} \mathrm{i}+0,6 \times \mathrm{SBi}$ & fair \\
D & $\bar{X}+0,6 \times \mathrm{SBi}<\mathrm{X} \leq \bar{X} \mathrm{i}-1,8 \times \mathrm{SBi}$ & bad \\
E & $\mathrm{X}<X \mathrm{i}-1,8 \times \mathrm{Sbi}$ & very bad \\
\hline
\end{tabular}

Description:

$\bar{x}$ : ideal average $=1 / 2$ (ideal maximum score + ideal minimum score)

Sbi: ideal standard deviation $=1 / 6$ (maximum score minimum score)

$\mathrm{X}$ : obtained score

In this research development, the value of the illustrated books feasibility is B which means good, therefore, the books are appropriate to be used as the learning media, (3) media effectiveness analysis, is used to know the effectiveness of illustrated story books to students' learning motivation and beginning reading skill.

\section{Results and Discussion}

Results

This research aimed at producing illustrated story books which are appropriate and effective to improve beginning reading skill and learning motivation of the first grade students of State Elementary School in Timbulharjo, Sewon, Bantul.

The initial step is gathering information through interview and field observation. Based on the data, it can be concluded that the illustrated story books can solve the problem of the first grade students of State Elementary School in Timbulharjo, Sewon, Bantul. The dominated problems are the low beginning reading skill and learning motivation of the students.

In this research, the students' beginning reading skill and learning motivation are improved by using illustrated story books and the books are used as teacher's handbook and guideline. The books are based on the need analysis which shows that the available books at school cannot optimally improve students' beginning reading skill and learning motivation.

The developed illustrated story books concern the aspects which can help to improve students' beginning reading skill and learning motivation. The skill of beginning reading is improved through the content of the story which is contextual to the students' surrounding. Motivation of the students are improved through the motivated words in the story. The content of the story to improve the students' beginning reading skill involves the subject of Indonesian Language, Math, Civic Education, Arts and Culture, and Physical Education. Therefore, students do not only practice to read the texts but also to understand the material of the other subject involved within the story. The combination of stories and interesting pictures is expected to improve students' motivation to read.

Illustrated story books are arranged to attract the students to read and therefore the books are appropriate to improve their beginning reading and learning motivation. The reading skill and learning motivation are interrelated each other. Students who have high learning motivation give strong influence to their beginning reading skill.

The arranged story books are validated by media and material expert and teacher at the place where the research is held. Through the validation of experts and teacher and the finding in the field tryout, this research produces the books which are appropriate and effcetive to improve students' beginning reading skill and learning motivation.

The result of product feasibility as validated by media expert is 58 which is in very good category. It means that the developed illustrated books have fulfilled the criteria of interesting display design, suitable pictures and colours, suitability of pictures with student environment, readable letters, suitability of pictures with student characteristics, and ability to build the beginning reading skill. The results of the assessment are illustrated in Table 2 . 
Jurnal Prima Edukasia, 6 (2), July 2018 -124

Felix Baskara Bhakti Utomo

Table 2. The Assessment Result of Feasibility by the Media Expert

\begin{tabular}{|c|c|c|}
\hline Number & Indicator & Score \\
\hline 1. & Display design & 16 \\
\hline 2. & Colour and picture selection & 4 \\
\hline 3. & $\begin{array}{l}\text { Suitability of pictures with the } \\
\text { students environment }\end{array}$ & 12 \\
\hline 4. & Use of letters & 11 \\
\hline 5. & $\begin{array}{l}\text { Suitability of pictures with } \\
\text { student characteristics }\end{array}$ & 11 \\
\hline 6. & $\begin{array}{l}\text { Ability to build beginning } \\
\text { reading skill }\end{array}$ & 4 \\
\hline & Total & 58 \\
\hline
\end{tabular}

The result of product feasibility as validated by material expert is 70 which is in very good category. It means that the developed story books have fulfilled the criteria of suitability of theme, coherence of each element, combination of picture and language, originality, suitability of cognitive development steps, ability to attract interest and motivation, ability to improve begining reading skill, suitability of materials to core and basic competencies (KI KD) of Curriculum 2013, and information clarity. The result of the assessment are illustrated in Table 3.

Table 3. The Assessment Result of Feasibility by Media Expert

\begin{tabular}{|c|c|c|}
\hline No. & Indicator & Score \\
\hline 1. & Suitability of theme & 4 \\
\hline 2. & Coherence of each element & 7 \\
\hline 3. & $\begin{array}{l}\text { Combination of picture and } \\
\text { language }\end{array}$ & 7 \\
\hline 4. & Originality & 7 \\
\hline 5. & $\begin{array}{l}\text { Suitability of cognitive } \\
\text { development steps }\end{array}$ & 8 \\
\hline 6. & $\begin{array}{l}\text { Ability to attract interest and } \\
\text { motivation }\end{array}$ & 6 \\
\hline 7. & $\begin{array}{l}\text { Ability to improve beginning } \\
\text { reading skill }\end{array}$ & 7 \\
\hline 8. & $\begin{array}{l}\text { Suitability of materials to core and } \\
\text { basic competencies (KI KD) of } \\
\text { Curriculum } 2013\end{array}$ & 13 \\
\hline 9. & Information clarity & 11 \\
\hline & Total & 70 \\
\hline
\end{tabular}

The field tryout is limited to the 1A class of State Elementary School in Timbulharjo with the subject of three students and one teacher. In the limited field tryout, the learning with the developed product hasn't been held. This limited field tryout aimed to get information or suggestion from teacher and students about the developed product. The try out implementation is to give the illustrated story books to students and teacher. The data gained in this tryout are the response of students and teacher.
The total of teacher's response in the initial operational test is 54 which is in very good category. The result shows that the teacher responds the developed illustrated books positively. The teacher, as the questionnaire respondent, writes the suggestion to revise the product.

The average score of student response in the initial operational test is 7.67 which is in very good category. The result shows that the students respond the developed illustrated books positively. The students, as the questionnaire respondent, write the suggestion to revise the product. However, all the students do not give any suggestion to the developed media.

The field tryout is expanded to the students of 1A class of State Elementary School in Timbulharjo with the subjects of 12 students and one teacher. In the expanded field try out, the learning with the developed product hasn't been held. The aim of the expanded field try out is to gain information or suggestion from students and teacher about the developed product. The implementation of expanded field tryout is to give the illustrated story books to students and teacher to read. The data gained in this limited tryout are the response from the students and the teacher.

The total of teacher's response in the expanded operational try out is 54 which is in very good category. The result shows that the teacher responds the product of developed illustrated books positively. Teacher, as the questionnaire respondent, does not give any suggestion to revise the illustrated story books.

The average score of students' response in the expanded operational tryout is 8 which is in very good category. The result shows that the students respond the product of developed illustrated books positively. The students, as the questionnaire respondent, are expected to give suggestion to revise the illustrated story books. However, all the students do not give any suggestion to the developed media.

The operational field try out is held at State Elementary School in Timbulharjo for six times from May $22^{\text {nd }}$ to June $2^{\text {nd }}, 2017$ with 22 students of $1 \mathrm{~B}$ as the experiment class and 22 students of $1 \mathrm{C}$ as the control class. The implementation of operational field tryout uses the final product which has been revised from the expanded tryout. Experiment class is the class which implements the learning with the developed illustrated books and the control class is the class which implements the learning without the developed illustrated books. Data of operational try out result are the data of students' learning motivation 
observation and data of pre-test and post-test before and after using the illustrated story books in order to know their beginning reading skill.

The total of teacher's response in the operational try out is 54 which is in very good category. The result shows that the teacher responds the product of developed illustrated books positively.

The data of students' response are used to know the impression and opinion of the students after using the illustrated story books. The students' response are that the pictures and the stories are interesting and exciting, the stories are easy to understand and help the students to improve their beginning reading skill.

The average score of students' response in the operational try out is 7.45 which is in very good category. The result shows that the students respond the product of developed illustrated books positively.

The scale of learning is implemented in the experiment and control class to know the improvement of students' learning motivation. The scale of learning motivation in the operational try out is conducted every day in the experiment and control class. The results are illustrated in Table 4.

Table 4. The data of Students' Learning Motivation Scale in the Experiment and Control Class

\begin{tabular}{ccc}
\hline \multirow{2}{*}{ Category } & \multicolumn{2}{c}{ Total Student } \\
\cline { 2 - 3 } & Control Class & Experiment Class \\
\hline Very good & 8 & 16 \\
Good & 11 & 6 \\
Fair & 3 & 0 \\
Bad & 0 & 0 \\
Very bad & 0 & 0 \\
Average & $\mathbf{5 4 , 9 5}$ & $\mathbf{6 2 , 9 5}$ \\
\hline
\end{tabular}

Based on Table 4, it can be seen that the average score of students' learning motivation in the control class is 54,95 and in the experiment class is 62,95 . The result of the students' learning motivation in the operational test in the experiment class is higher than the control class.

Based on Figure 1, the score of students' learning motivation in experiment class is higher than control class. The test of beginning reading skill aimed at knowing how far the students' improvement is after using the illustrated story books in the learning process. The test of beginning reading skill is using the pre-test and post-test both in experiment and control class. The comparison of beginning reading skill results in the experiment and control class based on the average score is presented in Table 5.

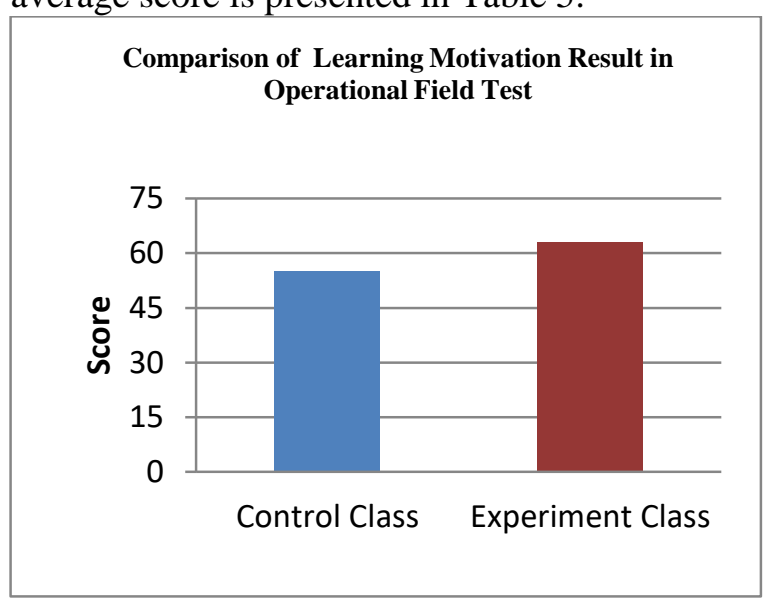

Figure 1. Diagram of Learning Motivation Result Comparison in Operational Field Test

Table 5. Comparison of Students' Beginning Reading Skill Results in Operational Field Try out.

\begin{tabular}{cccc}
\hline \multicolumn{2}{c}{ Control Class } & \multicolumn{2}{c}{ Experiment Class } \\
\hline PreTest & PostTest & PreTest & PostTest \\
$\mathbf{3 6 , 8 2}$ & $\mathbf{4 0 , 3 6}$ & $\mathbf{4 1 , 1}$ & $\mathbf{4 6 , 0 4}$ \\
\hline
\end{tabular}

Based on Table 5, the average score of students' beginning reading skill in the control class improves from 36,82 to 40,36 . The average score of students' beginning reading skill in the experiment class also improves from 41,1 to 46,04 . The comparison of beginning reading skill average score in operational try out is presented in Figure 2.

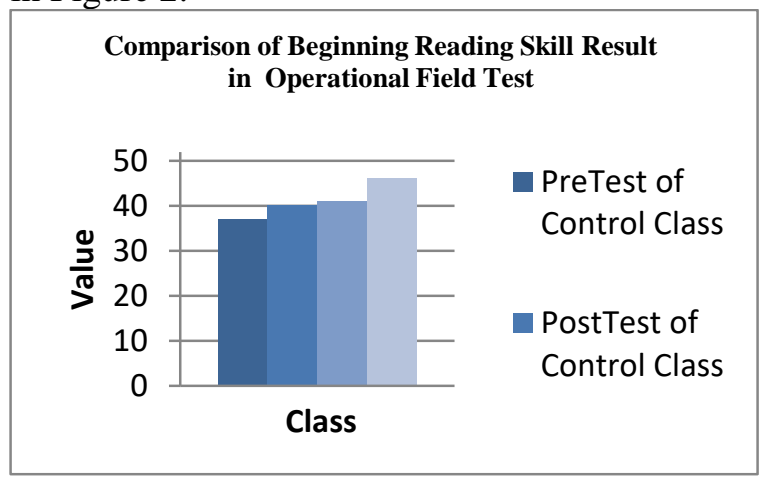

Figure 2. Diagram of Beginning Reading Skill Comparison in Operational Field Test

\section{Discussion}

The people who are involved in the development of illustrated story books are the writer as the content developer, illustrator as the picture design developer, the lecture, and two validators. The validators are the material expert and the learning media expert. 
Jurnal Prima Edukasia, 6 (2), July 2018 -126

Felix Baskara Bhakti Utomo

The illustrated story books are designed to improve students' beginning reading skill and learning motivation. Their reading skill is improved due to the words in the books which are easy to understand. Moreover, the interesting illustration is also able to gain students' interest to keep reading the books.

Students' learning motivation are improved since the books contains the texts which is contextual and related to their daily activities. Students' reading skill and learning motivation have linear relationship. Students who have high learning motivation are expected to have high reading skill too.

The developed illustrated story books are full of pictures and colors and have less words, therefore, the books are interesting to students. The development of illustrated story books concerns the criteria of the good learning media: (1) the quality of the content and its purpose (media), and (2) the learning quality (material). Therefore, the illustrated story books are expected to be the appropriate and effective media to improve students' learning motivation and beginning reading skill.

The illustrated story books are used for six days of learning. The books consist of the front cover which contains the title and illustration, the inner front cover which contains the column to write the student name, the content of the illustrated story book, the inner back cover which contains the summary (science information) of the book, and the back cover which contains the synopsis of the story.

The illustrated story books are arranged to attrack students' attention to read, therefore the books are suitable to improve students' learning motivation and beginning reading skill. The reading skill and learning motivation are interrelated each other which means that students who have high learning motivation can give the big influence to their beginning reading skill. This means that the learning purpose is achieved as stated by Herusantosa (Abbas, 2006, p.103) that the students are able to pronounce and understand the simple sentences written in the right intonation, and they are able to read or write words or simple sentences fluently and accurately in a relatively short time.

Nambiar (1993, p.2) explains that the benefit of reading favorite books repeatedly is that the students become more sensitive to the written language in the books. Students learn to pronounce the words based on the writing symbols. Azmussya'ni \& Wangid (2014) show that the use of pictures in the learning process can (1) improve student motivation to learn happily, more free, more active, and more productive, (2) improve student writing skill, (3) improve student skill in the use of spelling and punctuation. Therefore, the illustrated story books which are read repeatedly can improve the students' interest to read and make the students become more active to learn since they are motivated to know many things about the books.

The developed illustrated story books contain the word choice, language, story, and color combination which are adjusted to the characteristics of first grade students. This makes the students become more enthusiastic to learn. Burak (2014) states that a teacher should concern the level in motivating students, in order to be successful to do something. Teacher should be more careful to give the assignments which are adjusted to the students' age level. If students can reach the balance of assignment difficulty level to their ability, they will feel that the learning is fun and they are motivated to complete the assignments. If the students fail to reach the balance, it will lead to grow negative motivation. If the assignments are too difficult and the student ability is poor, it will grow the anxiety within the student. In other hand, if the assignments given are too easy and the student ability is very good, it will make the student get bored.

The developed illustrated story books are able to improve students' beginning reading skill. By using technologies, the products are better than those which are made manually. Odera (2011, p. 283) states that the use of technology and learning media are expected to motivate the students during the learning process. Media has a strong influence to the learning process.

The motivating words should be included in the instructional sentence of assignments, reading texts, and at the end of the learning process, therefore the words can help students to feel motivated. According to Lemos \& Verissimo (2014, p.935) for elementary students at the lower grade, the learning activities need more extrinsic motivation to make them more enthusiastic to do the assignments. Pictures, letters, and colour combination which are interesting and appropriate to the students' characteristics can also help students to feel motivated.

Learning motivation and beginning reading skill has a linear relationship. Students who have high learning motivation tend to have very good beginning reading skill. The research of Blazer (2010, p.9) shows that students who are 
motivated intrinsically and extrinsically look more active in learning for their own purpose, feel happy to do the tasks, and finally their achievement are improved too. In line with that opinion, Amrai, Motlagh, Zalani, \& Parhon (2011, p.402) states that motivation has a positive relationship to the learning achievement. Students who are motivated to learn will try hard to complete the challenge or difficult assignment in order to gain maximum comprehension.

Therefore, the development of illustrated story books in this research can improve students' beginning reading skill and learning motivation. The high learning motivation will improve students' beginning reading skill. The motivated students try hard to practice reading words or difficult sentences and gain mastery. The word choice, language, interesting pictures, colour combination, and the content of the stories which are appropriate to the students' daily life become the main factors in improving students' learning motivation and beginning reading skill.

\section{Conclusion}

This research shows that the product of illustrated story books developed in this research are appropriate and effective to be used to improve beginning reading skill and learning motivation of the first grade students. The theme of the illustrated story books is natural disaster. The improvement of the students can be seen from the average score of beginning reading skill before and after using the illustrated story books. The average score of beginning reading skill before using the illustrated story books is 41 and after using them is 46 . Based on the paired sample $t$-test, the gained probability score is $(\mathrm{p})<$ 0,05 . Therefore, it can be concluded that there is a significant difference on the effectiveness of the beginning reading skill before and after using the illustrated story books in learning.

\section{References}

Abbas, S. (2006). Pembelajaran bahasa Indonesia yang efektif di sekolah dasar. Jakarta: Departemen Pendidikan Nasional.

Akhadiah, S. (1992). Membaca sebagai keterampilan dasar. Jakarta: Dekdikbud

Amrai, K., Motlagh, S. E., Zalani, H. A., \& Parhon, H. (2011). The relationship between academic motivation and academic achievement students. ProcediaSocial and Behavioral Sciences, 15, 399402.
Azmussya'ni, A., \& Wangid, M. (2014). Peningkatan keterampilan menulis menggunakan pendekatan proses dengan media gambar di SDN 3 Sakra. Jurnal Prima Edukasia, 2(1), 1-13. doi:http://dx.doi.org/10.21831/jpe.v2i1.26 40

Blazer, C. (2010). Twenty strategies to increase student motivation. Research Service, 907, $1-13$.

Borg, W. R. \& Gall, M. D. (1983). Educational research an introduction $\left(4^{\text {th }} \mathrm{ed}\right)$. New York, NY.: Longman Inc.

Brophy, J. (2013). Motivating students to learn. New York, NY.: Routledge.

Burak, S. (2014). Motivation for instrument education: A Study with the perspetive of expetancy-value and flow theories, Eurasian Journal of Educational Research, 55, 123-136. http://dx/doi.org/10/14689/ejer.2014.55.8

Byrnes, J. P. (2008). Cognitive development and learning in instructional contexts. Boston: Allyn and Bacon.

Dick, W., Carey, L., \& Carey, J. O. (2009). The systematic design of instruction. New York, N.Y.: Pearson.

Elliot, S. N., Kratochwill, T. R., Cook, J. L., Travers, J. F. (2000). Educational Psychology: Effectivve teaching, effective learning. $\left(3^{\text {th }}\right.$ ed). Boston: McGraw Hill.

Faizah, U. (2009). Keefektifan cerita bergambar untuk pendidikan nilai dan keterampilan berbahasa dalam pembelajaran bahasa Indonesia. Jurnal Cakrawala Pendidikan, $3(3)$. doi:http://dx.doi.org/10.21831/cp.v3i3.30 2

Fathurrohman, P., \& Sutikno, S. (2014). Strategi belajar mengajar. Bandung: Refika Aditama.

Hamalik, O. (2004). Psikologi belajar dan mengajar. Bandung: PT Sinar Baru Algensindo.

Hamdu, G., \& Agustina, L. (2011). Pengaruh motivasi belajar siswa terhadap prestasi belajar IPA di sekolah dasar. Jurnal Penelitian Pendidikan, 12(1), 90-96.

Hidayat, A., \& Dwiningrum, S. (2016). Pengaruh karakteristik gender dan motivasi belajar terhadap prestasi belajar matematika siswa SD. Jurnal Prima Edukasia, 4(1), 32 - 45. doi:http://dx.doi.org/10.21831/jpe.v4i1.76 92 
Lemos, M. S., \& Veríssimo, L. (2014). The relationships between intrinsic motivation, extrinsic motivation, and achievement, along elementary school. Procedia Social and Behavioral Sciences, 112, 930-938

Levey, S., \& Polirstok, S. (2011). Languange development: understanding languange diversity in the classroom. London: SAGE Publications

Mitchell, D., Waterbury, P., \& Casement, R. (2002). Children's literature: An invitation to the world. Allyn \& Bacon.

Moldovan, O. D. (2014). Intrinsic and extrinsic motivation to primary school children. Journal Plus Education, 10(1), 203-211.

Nambiar, M. (1993). Early reading instruction big books in the ESL classroom. Melta International Conference.

Odera, F. Y. (2011). Motivation: The most ignored factor in classroom instruction in Kenyan secondary schools. International journal of Science and Technology, 1(6), 283-288.

Rahim, F. (2008). Pengajaran membaca di sekolah dasar. Jakarta: Sinar Grafika Offset

Republik Indonesia. (2003). Undang-Undang RI Nomor 20, Tahun 2003, tentang Sistem Pendidikan Nasional.

Santrock, J. W. (2011). Educational psychology. $\left(5^{\text {th }}\right.$ ed). New York: Quad Graphics.
Schunk, D. H., (2012). Learning theories an educational perspective. ( $6^{\text {th }}$ ed). Boston: Pearson Education.

Sudjana, N. \& Rivai, A. (2010). Media pengajaran: Pengunaan dan pembuatannya. Bandung: Sinar Baru Algesindo.

Supartini, E. (2001). Diagnostik kesulitan belajar dan pengajaran remidial. Yogyakarta: FIP UNY.

Susiani, L. (2006). Bikin Komik. Yogyakarta: Andi Offset.

Suwandi, I. K., \& Masruri, M. S. (2016). Pengembangan picture book sejarah nasional dengan pendekatan tematik terpadu unruk kelas iv sekolah. Jurnal Prima Edukasia, 4(1), $79 \quad$ - 92. doi:http://dx.doi.org/10.21831/jpe.v4i1.77 47

Sindo. (12 Mei 2016). Tingkat minat baca masyarakat rendah. SINDO, retrived from http://koran-sindo.com/page/news/2016$05-$

12/5/171/Tingkat_Minat_Baca_Masyarak at_Rendah

Uno, H. B. (2008). Teori motivasi \& pengukurannya analisis di bidang pendidikan. Jakarta: Bumi Aksara.

Widoyoko, S. E. P., \& Qudsy, S. Z. (2009). Evaluasi program pembelajaran: panduan praktis bagi pendidik dan calon pendidik. Yogyakarta: Pustaka Pelajar. 